\title{
Efficient Removal of Copper and Cadmium from Contaminated Soil Utilizing Electrokinetic Process
}

\author{
Muhammad Saleem ${ }^{1}{ }^{a}$ \\ ${ }^{1}$ Department of Civil Engineering, Jubail University College \\ Keywords: soil decontamination, heavy metal, removal efficiency, economy, operating parameters, electrokinetic process \\ https://doi.org/10.53370/001c.28950
}

\section{Yanbu Journal of Engineering and Science}

Vol. 18, Issue 1, 2021

\begin{abstract}
Present manuscript demonstrates the efficient removal of copper and cadmium from contaminated soil utilizing electrokinetic process. The results of systematic bench-scale study on improved extraction of copper and cadmium shows the suitability of process to decontaminate low permeable soil. The influence of operating parameters such as electrode material, soil $\mathrm{pH}$, current density, soil temperature, inter-electrode spacing and initial soil moisture content on the decontamination performance is investigated. Study revealed that, removal of copper and cadmium reached to $89.4 \%$ and $62.7 \%$ respectively while using titanium electrodes. Removal efficiency improved with the increase in current density, soil temperature and initial soil moisture content. About $74.5 \%$ of copper removal achieved within 20 hours at soil temperature of $35^{\circ} \mathrm{C}$ and current density was kept at $9.3 \mathrm{~mA} / \mathrm{cm}^{2}$. During this study, soil pH decreased from 6.7 to 2.4 near anode and reached up to 12.3 near cathode resulting in augmented metal removal. An improvement of $33 \%$ in removal efficiency observed when moisture content increased from $45 \%$ to $73 \%$. Rate of metal removal increased as the inter-electrode spacing decreased to $15 \mathrm{~cm}$, which demonstrated the highest copper removal at a current density of $9.3 \mathrm{~mA} / \mathrm{cm}^{2}$. The maximum energy consumption found to be $5.2 \mathrm{kWh} / \mathrm{m}^{3}$ of soil volume demonstrated the economy of process, which can be scaled up at cleanup sites.
\end{abstract}

\section{INTRODUCTION}

Increasing degradation of soil with variety of contaminants including heavy metals is causing significant perturbation to the ecology. ${ }^{1}$ In many parts of the world, especially in chemical and power producing industry, soil contamination is increasing at an alarming rate. ${ }^{2}$ Heavy metal concentrations more than the permissible limits will generally result in severe negative effects on ecological components in the environment and human health. ${ }^{3}$ Due to the higher toxicity level and hazards associated with the metal contamination the Maximum Allowable Concentration Limits (MACL) in soil and in the discharge effluent from industry are set to very low values (table 1 ).

Researchers have developed technologies in order to remediate such contaminated soils, however, most of them demonstrated significantly lower remediation efficiencies specially when dealing with low permeable soils. ${ }^{8}$ Remediation of soil with electrokinetic technique found to be a practical, economical and efficient decontamination technique. ${ }^{9}$ The electrokinetic technology is a combination of three processes namely; electroosmosis, electrophoresis and electrochemical processes. ${ }^{10}$ With the embarkment of new millennium research on the application of electroki- netic process for the decontamination of soil congregate the attention of many researchers. Some researchers tried to improve the extraction efficiency of process by utilizing various additives including benzoic acid cometabolite, ${ }^{11}$ Zinc oxide (ZnO)-Citrus sinensis nano-additive ${ }^{12}$ and Ethylenediaminetetraacetic acid (EDTA). ${ }^{13}$

A number of researchers explored this area and a large number of laboratory as well as pilot scale studies have been done that describe the contaminant transport in low permeable media. $8,14,15$ However, there is a need to explore various operating parameters on which the efficiency and economy of the process depend. Current research is struggling to overcome the mass transfer limitations and reduce the cost and time of treatment. ${ }^{10}$

\section{MATERIALS AND METHODS}

A laboratory scale rectangular electrokinetic setup including electrodes and other accessories was prepared in the environmental engineering laboratory of Civil Engineering department at Jubail University College, Saudi Arabia.

The electrokinetic plexiglas cell is a rectangular box having dimensions of $36 \mathrm{~cm} \times 30 \mathrm{~cm} \times 25 \mathrm{~cm}$ as shown in figure 1. Cell having one anode and one cathode with thick- 
TABLE 1. MAXIMUM PERMISSIBLE CONCENTRATION LIMITS OF SOME METAL IN SOIL AND IN THE DISCHARGE EFFLUENT FROM INDUSTRY.

\begin{tabular}{|l|c|c|c|c|}
\hline \multirow{2}{*}{ Metals } & \multicolumn{4}{|c|}{ MACL of Metals in Soil Used for Land Applications (mg/kg) } \\
\hline & ^WHO & *US-EPA & ${ }^{* *}$ China & !Hungarian \\
\hline $\mathrm{Cd}$ & 0.003 & 1.6 & $0.3-0.6$ & 1 \\
\hline $\mathrm{Cr}$ & 0.1 & 120 & $150-300$ & 75 \\
\hline $\mathrm{Cu}$ & -- & 100 & -- & 75 \\
\hline $\mathrm{Pb}$ & 0.1 & 60 & 80 & 100 \\
\hline $\mathrm{Hg}$ & 0.08 & 0.5 & $0.3-1.0$ & 0.5 \\
\hline $\mathrm{Se}$ & -- & 1.6 & -- & 1 \\
\hline $\mathrm{Ni}$ & 0.05 & 32 & $40-60$ & - \\
\hline $\mathrm{Zn}$ & -- & 220 & -- & 40 \\
\hline $\mathrm{Ar}$ & -- & 14 & & 200 \\
\hline
\end{tabular}

${ }^{\wedge}$ Chiroma et al. ${ }^{4}$; *US-EPA ${ }^{5}$; **He et al. ${ }^{6}$; !Mayar ${ }^{7}$

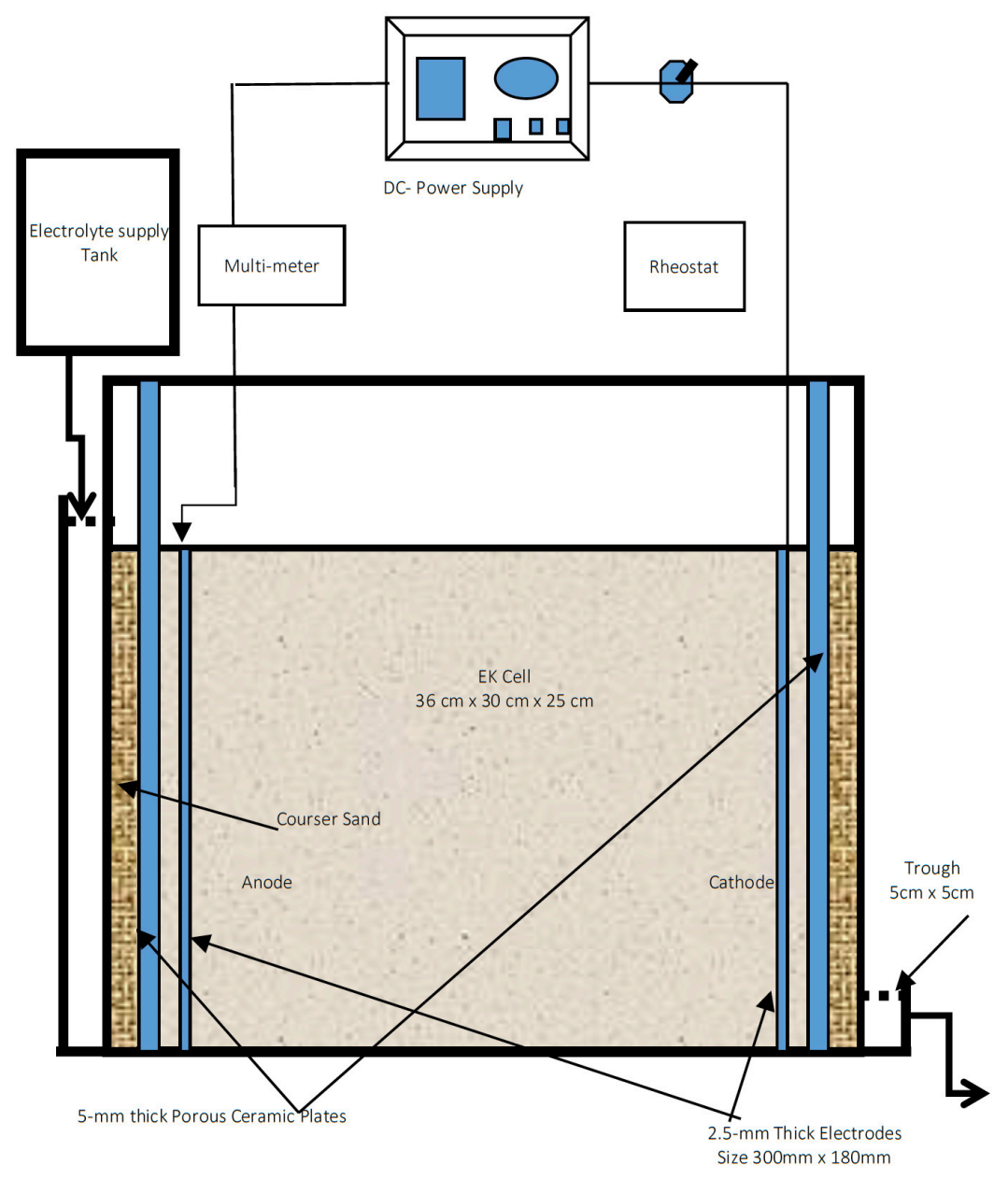

Fig. 1. Schematic of EK soil decontamination setup

ness of about $2.5-\mathrm{mm}$ having dimension of $28 \mathrm{~cm} \mathrm{x} 18 \mathrm{~cm}$. Electrodes are connected to a constant DC power supply source (GW Instek, SPD-3606 DC power supply) along with a rheostat (DDR/DNR/DSR series, MFPR, Hong Kong) and a multimeter (8846A, Fluke, USA) to adjust and monitor the voltage and current. Spacing between the electrodes were kept $15 \mathrm{~cm}$ in all experimental runs except during the study of inter-electrode separation. In order to provide drainage 
TABLE 2. XRD MINERALOGICAL ANALYSIS RESULTS OF SOIL SAMPLE.

\begin{tabular}{|l|l|}
\hline \multicolumn{1}{|c|}{ Mineral } & Percentage \\
\hline Quartz & 73.4 \\
\hline Calcite & 9.3 \\
\hline Kaolinite & 1.6 \\
\hline Albite & 3.8 \\
\hline Muscovite & 2.7 \\
\hline Thuringite & 1.6 \\
\hline Cristobolite & 1.4 \\
\hline Montmorilonite & 6.2 \\
\hline
\end{tabular}

TABLE 3. GEOTECHNICAL AND PHYSICOCHEMICAL CHARACTERISTICS OF SOIL SAMPLE.

\begin{tabular}{|l|c|}
\hline \multicolumn{1}{|c|}{ Parameter } & Value \\
\hline $\mathrm{pH}$ & $6.7 \pm 0.5$ \\
\hline Moisture content & $15.7-32.5 \%$ \\
\hline Buffering capacity & $0.1 \pm 0.01 \mathrm{mM} / \mathrm{g}$ \\
\hline Density & $1.18 \pm 0.01 \mathrm{~g} / \mathrm{cm} 3$ \\
\hline Porosity & $48.7 \pm 1.2 \%$ \\
\hline Sp. Gravity & $2.47 \pm 0.2$ \\
\hline Organic content & $0.13 \pm 0.2 \%$ \\
\hline Electrical conductivity & $67.4 \pm 1.5 \mu \mathrm{S} / \mathrm{cm}$ \\
\hline Hydraulic conductivity & $10^{-4}-10^{-3} \mathrm{~cm} / \mathrm{sec}$ \\
\hline Liquid limit & $25.8 \pm 0.5 \%$ \\
\hline Plastic limit & $16.2 \pm 0.8 \%$ \\
\hline Plastic index & $9.7 \pm 1.2$ \\
\hline
\end{tabular}

through cell-porous media, two 5-mm thick porous ceramic plates were provided at the end of the cell adjacent to a coarser sand layer which also prevent the flow of soil and loss of cell mass (figure 1). A separate electrolyte tank has been used to provide a controlled flow of $0.5 \mathrm{ml} / \mathrm{hr}$ except during study of initial soil moisture content. All the analysis performed was based on standard procedures. ${ }^{16}$

\section{RESULTS AND DISCUSSION}

XRD mineralogical analysis results of soil sample are presented in table 2. Results indicate the presence of major part of quartz and calcite. The clay fraction is mainly consisting of montmorillonite, muscovite and kaolinite. Therefore, it gives the partially swelling type characteristic to the soil sample. Calcite present in the soil (9.3\%) provided buffering during electrokinetic remediation runs. Soil samples were also analyzed from standard geotechnical and physicochemical analysis during electrokinetic remediation study and results of analysis are shown in table 3 . Results of soil metal analysis are presented in table 4 which is showing high concentration of copper and cadmium.

\subsection{EFFECT OF ELECTRODE MATERIAL}

The compatibility of electrode materials has great importance in electrokinetic process to improve and optimize the process efficiency and economy of the treatment process. Therefore, in order to select the suitable material for present study materials namely titanium, aluminum, nickel and 304 stainless steel were tested to find a suitable candidate electrode material.

Temporal variation of copper and cadmium at the middle of soil sample was monitored while applied current density was $9.3 \mathrm{~mA} / \mathrm{cm}^{2}$. Selected electrodes were tested and removal efficiency of metals were noted. Results are presented in figure 2 . It can be seen that the removal efficiency of all electrode materials are higher in case of copper removal as compared to cadmium. This may be attributed to the higher mass number of cadmium as compared to copper which is a significant factor in the mass transport through low permeable soils. ${ }^{17}$ 
Among all four types of studied electrode materials titanium and nickel demonstrated higher removal efficiency. However, highest removal efficiency was achieved in case of titanium electrode. Removal efficiency of titanium for copper and cadmium removal reached up to 89.4 and $62.7 \%$ respectively at the end of 100 hours run. It can be seen from figure 2, the removal efficiency for copper reached up to $74.5 \%$ within initial 20 hours of experimental run. Therefore, electrokinetic process with titanium electrode is capable of removing significant amount of metal from contaminated soil during initial 20 hours. As titanium electrode showed highest removal efficiency, remaining experimental runs were performed with titanium electrodes. The removal efficiency achieved in this study is higher than reported in literature. ${ }^{18,19}$

\subsection{VARIATION OF SOIL pH WITH TIME}

Variation in soil $\mathrm{pH}$ after 24 and 80 hours of experimental run at different points between electrodes is presented in figure 3. At the beginning of experimental run, $\mathrm{pH}$ of soil was determined and found to be 6.7. It can be seen from fig$\underline{\text { ure } 3}$ that the soil $\mathrm{pH}$ in the vicinity of anode is decreasing with time while an increasing trend observed around cathode.

Curves of figure shows that acid front moves across the soil from anode towards cathode and a base front moves from cathode to anode. However, acid front moves faster than the base front. This could be due to the mobility of $\mathrm{H}^{+}$ which exceeds the mobility of $\mathrm{OH}^{-}$. This shift in the curve is also reported by some researchers and attributed to the direction of electro-osmotic flow which is generally towards the cathode. ${ }^{20}$

As the decontamination of soil depends on metal ion solubility with either a low or a high $\mathrm{pH}$ throughout the soil and avoiding the conditions resulting in precipitation. Thus control of $\mathrm{pH}$ is of major importance in soil decontamination.

\subsection{EFFECT OF CURRENT DENSITY}

During this study applied DC current was varied in a controlled manner to achieve current density ranging from 2.5 $\mathrm{mA} / \mathrm{cm}^{2}$ to $12.2 \mathrm{~mA} / \mathrm{cm}^{2}$ during four experimental runs $(2.5$ $\mathrm{mA} / \mathrm{cm}^{2}, 5.5 \mathrm{~mA} / \mathrm{cm}^{2}, 9.3 \mathrm{~mA} / \mathrm{cm}^{2}$ and $\left.12.2 \mathrm{~mA} / \mathrm{cm}^{2}\right)$. Temporal variation in the copper and cadmium removal when different current densities were applied are presented in Figure 4.

The metal removal found to be augmented with the increase in the applied current density however; significant increase in cadmium removal (24.3\%) found as compared to copper $(8.6 \%)$ when current density increased from 2.5 $\mathrm{mA} / \mathrm{cm}^{2}$ to $12.2 \mathrm{~mA} / \mathrm{cm}^{2}$. It was found that at current density of $9.3 \mathrm{~mA} / \mathrm{cm}^{2}$ copper concentration reached below 83 $\mu \mathrm{g} / \mathrm{g}$ from $4975.6 \mu \mathrm{g} / \mathrm{g}$ at the end of experimental run (100 hours). However, further increase in applied current density does not improve the removal efficiency of process. Thus, current density $9.3 \mathrm{~mA} / \mathrm{cm}^{2}$ is a reasonable value for an effective copper and cadmium removal.
TABLE 4. RESULTS OF METAL ANALYSIS SHOWING BACKGROUND METAL CONCENTRATION PRESENT IN SOIL SAMPLE.

\begin{tabular}{|l|c|}
\hline Metal & Concentration $(\mu \mathrm{g} / \mathrm{g})$ \\
\hline $\mathrm{Na}$ & $4165.2 \pm 8.5$ \\
\hline $\mathrm{K}$ & $1306.3 \pm 5.5$ \\
\hline $\mathrm{Mn}$ & $752.9 \pm 2.5$ \\
\hline $\mathrm{Fe}$ & $67.4 \pm 1.5$ \\
\hline $\mathrm{Zn}$ & $11.6 \pm 1.2$ \\
\hline $\mathrm{Cr}$ & $22.4 \pm 1.5$ \\
\hline $\mathrm{Ni}$ & $0.7 \pm 0.01$ \\
\hline $\mathrm{Pb}$ & $0.2 \pm 0.01$ \\
\hline $\mathrm{Cu}$ & $4975.6 \pm 8.5$ \\
\hline $\mathrm{Co}$ & $0.3 \pm 0.01$ \\
\hline $\mathrm{Cd}$ & $926.3 \pm 1.5$ \\
\hline $\mathrm{V}$ & $16.3 \pm 1.2$ \\
\hline
\end{tabular}

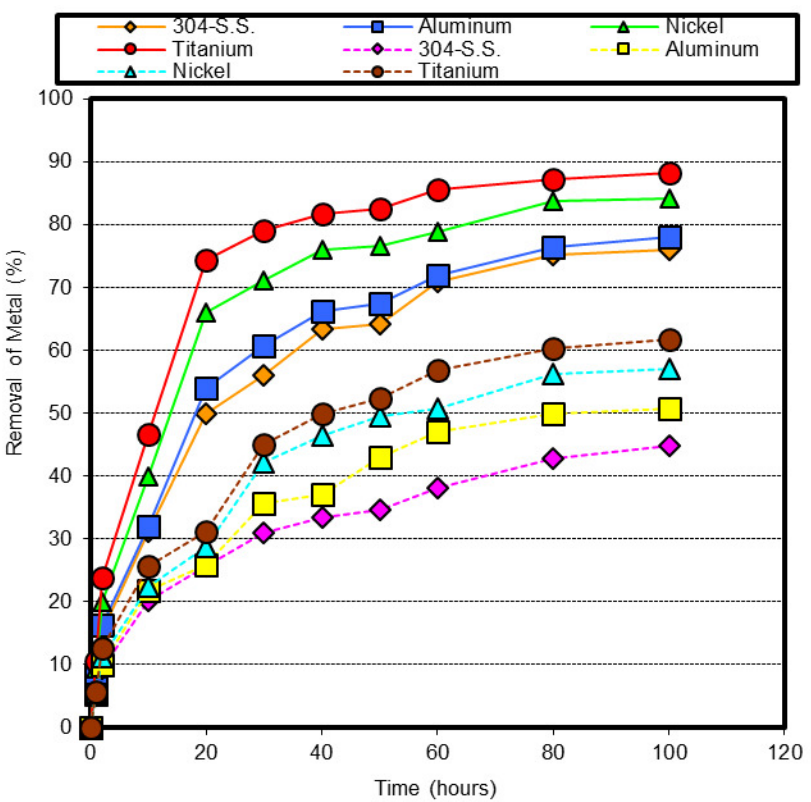

Fig 2. Temporal removal of copper and cadmium with different electrode materials ( - continues lines) and cadmium (- - - dotted lines)

\subsection{EFFECT OF SOIL TEMPERATURE}

Effect of soil temperature on copper removal efficiency was investigated in two experimental runs by keeping temperature of soil matrix around $20^{\circ} \mathrm{C}$ and $35^{\circ} \mathrm{C}$. An isotherm water-circulating bath (WCB Circulation water bath) was used and temperature of soil was maintained at desired value by keeping the electrochemical cell in the bath. Effect of soil temperature on the copper removal efficiency at $20^{\circ} \mathrm{C}$ and $35^{\circ} \mathrm{C}$ is shown in figure 5 .

Removal efficiency of the process reached to about $75 \%$ 
when the temperature was $35^{\circ} \mathrm{C}$ as compared to it was about $22 \%$ when the temperature was $20^{\circ} \mathrm{C}$ therefore, an increase of about $52 \%$ in the process efficiency was observed. However, with time this difference diminished and at the end of 100 hours of run it reached to about $16 \%$. Therefore, results suggested that the effect of soil temperature is very important during first few hours and it may significantly improve the removal efficiency of process. Therefore, further study is warranted to investigate the effects of soil drying which may result in soil shrinkage, cracks development and creation of irregular flow paths, which may ultimately cause termination of osmotic flow.

\subsection{EFFECT OF INTER ELECTRODES SEPARATION}

Inter-electrode separation is one of the important operating parameters of electrokinetic remediation method because the increase in the separation between electrodes will result in economical treatment and reduce the capital cost of treatment. However, it may result in reduction in the treatment efficiency of the process. Furthermore, increasing the inter-electrode separation will result in longer treatment time. ${ }^{21}$

Results presented in figure 6 show that the copper removal efficiency is increasing with the reduction in the inter-electrode separation. Maximum removal of copper achieved at separation of $15 \mathrm{~cm}$. It was observed that by increasing the inter-electrode separation from $15 \mathrm{~cm}$ to 30 $\mathrm{cm}$ there is a decrease in removal efficiency from $89.5 \%$ to $68.7 \%$. However, if separation decreased from $15 \mathrm{~cm}$ to 10 $\mathrm{cm}$ no improvement in removal efficiency was observed and at $5 \mathrm{~cm}$ separation trend shows a nonlinear behavior. The nonlinear behavior may be attributed to the transitions during buildup of double layer forces that are more effective near certain inter-electrode separation. Thus, copper removal efficiency is reduced beyond a separation of $15 \mathrm{~cm}$.

\subsection{EFFECT OF INITIAL SOIL MOISTURE CONTENT}

Moisture content in the soil matrix could be one of the important parameters, which may enhance the electrokinetic process efficiency. ${ }^{22}$

Results presented in figure 7 show that with the increase in soil moisture content the cooper removal is increasing especially during initial 20 hours of run. An increase in moisture content from $45 \%$ to $73 \%$ ( $29 \%$ increase) enhance the cooper removal up to $33 \%$ (at 20 hour). However, removal of copper declined after 40 hours of run and became almost constant which may be attributed to the drying of pore space and cracks formation in the soil matrix.

Overall, it was observed that the initial moisture content affects the electrokinetic process but it does not significantly influence the overall migration and removal of copper, and the results indicate that the soil moisture content initially affect migration and removal of copper until there is sufficient moisture present in the soil matrix.

\section{SUMMARY AND CONCLUSION}

Electrokinetic treatment process has been used successfully at many sites such as Jaslovske Bohunice and Chernobyl nu-

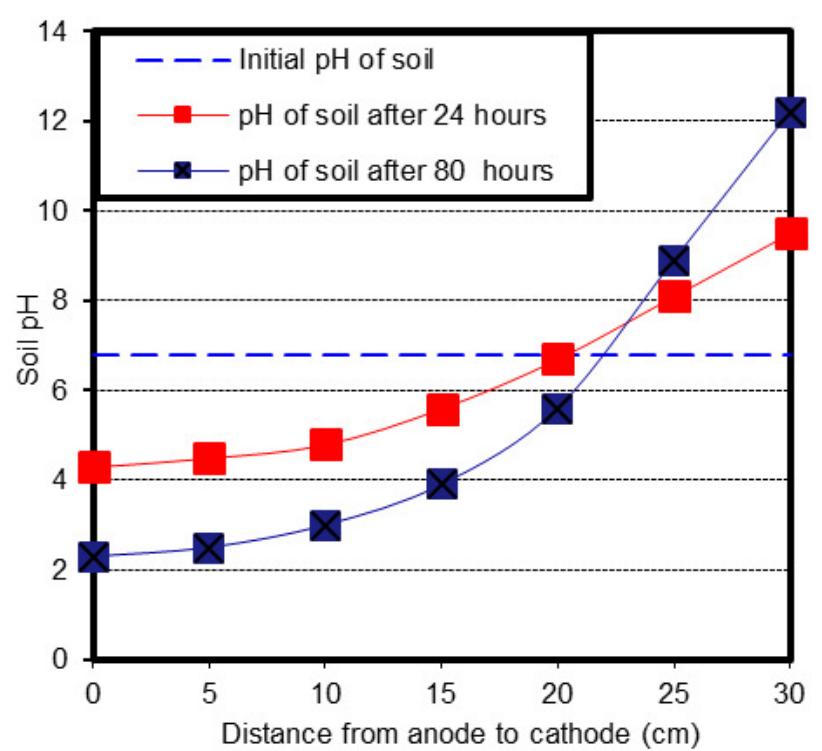

Fig 3. Variation of soil $\mathbf{p H}$ at different points between electrodes at 24 and 80 hours run

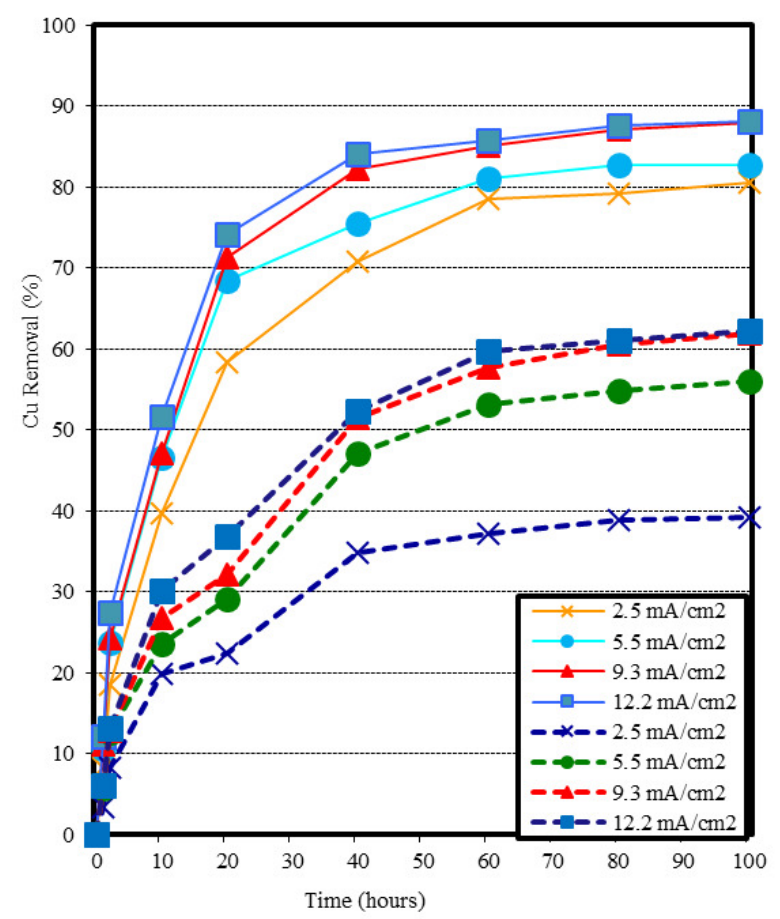

Fig 4. Effect of current density on the removal of copper and cadmium ( - continues lines) and cadmium (- - dotted lines)

clear power plant and many superfund sites for the removal of metals and other contaminants. ${ }^{23-26}$ A detailed laboratory scale study was performed to investigate the efficiency of the process in order to remove copper and cadmium from soil samples. Influence of operational parameters such as electrode material, soil $\mathrm{pH}$, current density, soil temperature, inter-electrode separation and soil moisture content on the treatment performance was investigated. Following are the conclusions drawn on the basis of the results ob- 
tained from study.

- Titanium found to be electrochemically most stable material among tested materials and showed minimum dissolution during experimental run. At the end of 100 hours run removal efficiency of titanium for copper and cadmium found to be $89.4 \%$ and $62.7 \%$ respectively.

- Low pH found to be favorable for copper removal from soil because of the more desorption of sorbed metals from soil surface occurred in the presence of $\mathrm{H}_{3} \mathrm{O}^{+}$.

- Metal removal is positively related to the current density. Results show that current density of $9.3 \mathrm{~mA} / \mathrm{cm}^{2}$ is capable of bringing the copper concentration below $83 \mu \mathrm{g} / \mathrm{g}$ from $4975.6 \mu \mathrm{g} / \mathrm{g}$ within 100 hours of experimental run.

- Effect of soil temperature on the copper removal efficiency was monitored and found that during initial 20 hours run removal efficiency of process improved by $52 \%$ while soil temperature increased from 20 to $35^{\circ} \mathrm{C}$. It seems that the increase in temperature enhanced the mobility of copper in the moist soil especially during first few hours.

- Rate of copper removal increased as the inter-electrode separation decreased. Maximum removal of copper achieved with a separation of $15 \mathrm{~cm}$. A reduction of inter electrode separation from 30 to $15 \mathrm{~cm}$ may increase copper removal efficiency from $68.7 \%$ to 89.5\%. But after an optimum separation electrostatic double layer formed due to the cations swarm near the soil particle surface which may dominate and suppressed the copper removal.

- A nonlinear behavior in removal efficiency observed at a separation of $5 \mathrm{~cm}$ and may be attributed to the transitions in overwhelming double layer forces becoming effective near certain inter-electrode separation.

- An increase of $29 \%$ moisture content improve the removal of copper up to $33 \%$ during initial 20 hours of run. However, it does not significantly enhance the overall migration of metal ions.

Application of electrokinetic process is quite tempting since it offers an elucidation to remediate sites that would otherwise be cost-prohibitive. Scale-up considerations has been evaluated by researchers and found better results with large scale devices using lesser energy and additives. ${ }^{27,28}$ There is a great potential for remediation of actual contaminated sites. However, there still exists a need for wellplanned and well-instrumented application of technology in the field. Site characteristics and inherent complexity with the electrokinetic process need to be investigated. Finally, optimization of operational parameters is imperative for each site to be decontaminated to obtain maximum achievable efficiency of the electrokinetic process.

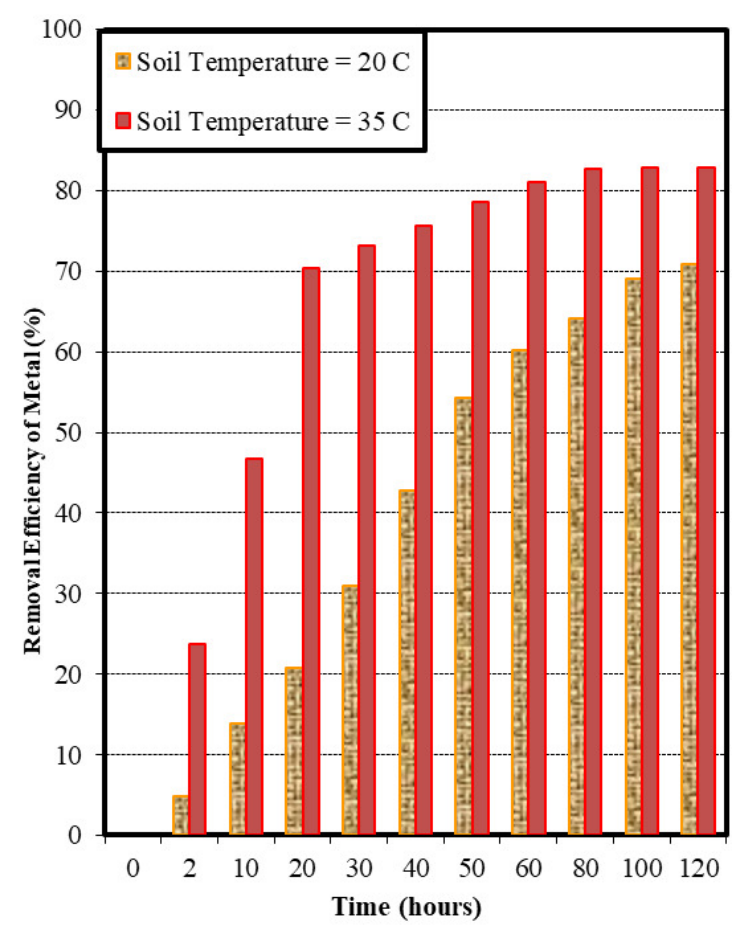

Fig. 5. Removal efficiency of EK for copper process at $20 \mathrm{C}$ and $35 \mathrm{C}$

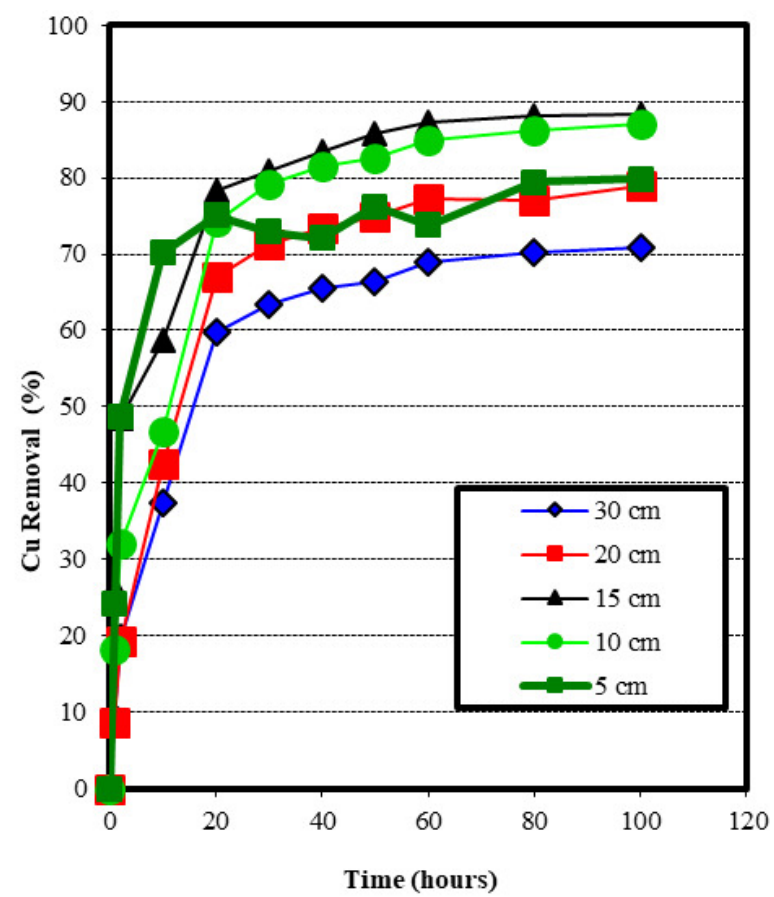

Fig. 6. Effect of inte-electrode separation on copper removal 


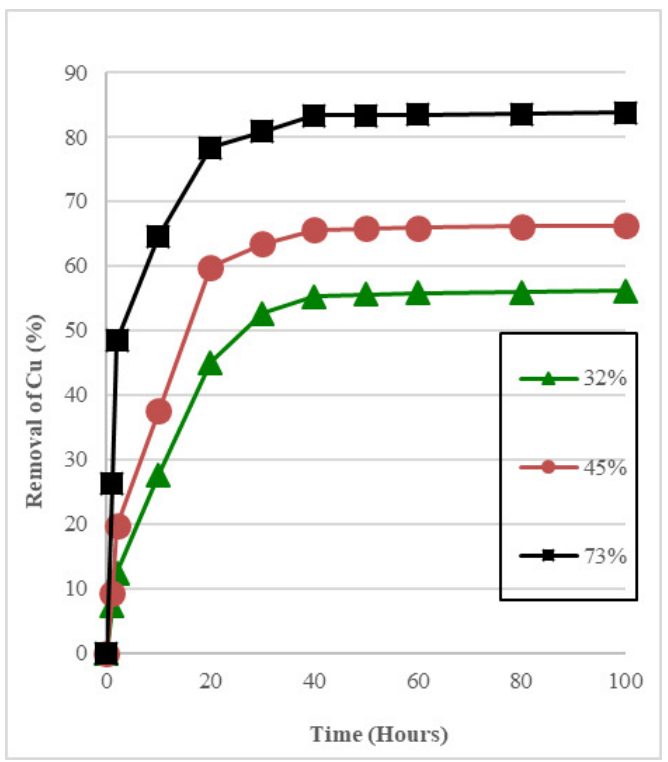

Fig. 7. Effect soil moisture content on copper removal

This is an open-access article distributed under the terms of the Creative Commons Attribution 4.0 International License (CCBY-4.0). View this license's legal deed at http://creativecommons.org/licenses/by/4.0 and legal code at http://creativecommons.org/licenses/by/4.0/legalcode for more information. 


\section{REFERENCES}

1. Mbagwu JSC, Obi ME. Land degradation, agricultural productivity and rural poverty. environmental implications Proc of 28th Ann Conference of SSS Nigeria. 2005;1:1-11.

2. Ahmad AM, Al-Attas O, Mohiuddin S, Al-Suwaiyan MS. Regulating underground fuel storage tanks (USTS), benefits and challenges. In: The 6th Saudi Engineering Conference. KFUPM, Dhahran, Saudi Arabia; 2002.

3. Kinuthia GK, Ngure V, Beti D, Lugalia R, Wangila A, Kamau L. Levels of heavy metals in wastewater and soil samples from open drainage channels in Nairobi, Kenya: Community health implication. Sci Rep. 2020;10(1):41598-41020. doi:10.1038/s41598-020-65 $\underline{359-5}$

4. Chiroma TM, Ebewele RO, Hymore FK.

Comparative assessment of heavy metal levels in soil, vegetables and urban grey waste water used for irrigation in Yola and Kano. International refereed journal of engineering and science. 2014;3(2):01-09.

5. US-EPA (United States Environmental Protection Agency. Standards for the Use or Disposal of Sewage Sludge, 40 CFR Part 503. Washington, D.C: USEPA; 1997.

6. He Z, Shentu J, Yang X, Baligar VC, Zhang T, Stoffella PJ. Heavy metal contamination of soils: sources, indicators and assessment. Journal of Environmental Indicators. 2015;(9):17-18.

7. Mayar K. Government Regulations. Government of Hungry. Vol 10.; 2000:3156-3167.

8. Du J, Zhang B, Li J, Lai B. Decontamination of heavy metal complexes by advanced oxidation processes: A review. Chinese Chemical Letters. 2020;31(10):2575-2582. doi:10.1016/j.cclet.2020.07.0 $\underline{50}$

9. Mao X, Shao X, Zhang Z. Pilot-scale electro-kinetic remediation of lead polluted field sediments: Model designation, numerical simulation, and feasibility evaluation. Environ Sci Eur. 2019;31(1):1-20. doi:10.1 186/s12302-019-0209-x

10. Fdez-Sanromán A, Pazos M, Rosales E, Sanromán MÁ. Prospects on integrated electrokinetic systems for decontamination of soil polluted with organic contaminants. Current Opinion in Electrochemistry. 2021;27:100692. doi:10.1016/j.coelec.2021.100692
11. Rabbi MF, Clark B, Gale RJ, Ozsu-Acar E, Pardue J, Jackson A. In situ TCE bioremediation study using electrokinetic cometabolite injection. Waste Management. 2000;20(4):279-286. doi:10.1016/s095 $\underline{6-053 \times(99) 00329-3}$

12. Ajayi OO, Omowa OF, Abioye OP, et al. Finite element modelling of electrokinetic deposition of zinc on mild steel with $\mathrm{ZnO}$-citrus sinensis as nanoadditive. In: CFD Modeling and Simulation in Materials Processing 2018. Cham: Springer; 2018:199-211. doi:1 0.1007/978-3-319-72059-3_19

13. Torabi MS, Asadollahfardi G, Rezaee M, Panah NB. Electrokinetic removal of $\mathrm{Cd}$ and $\mathrm{Cu}$ from mine tailing: EDTA enhancement and voltage intensity effects. J Hazard Toxic Radioact Waste.

2021;25(2):05020007. doi:10.1061/(asce)hz.2153-551 $\underline{5.0000579}$

14. Prozorov LB, Scheglov MY, Nikolaevsky VB, Shevtsova EV, Korneva SA. The influence of electric parameters on the dynamic of the electrokinetic decontamination of soils. J Radioanal Nucl Chem. 2000;246(3):571-580.

15. Alshawabkeh AN, Bricka RM, Gent DB. Pilot-Scale electrokinetic cleanup of lead-contaminated soils. $J$ Geotech Geoenviron Eng. 2005;131(3):283-291. doi:1 0.1061/(asce)1090-0241(2005)131:3(283)

16. Clesceri LS, Greenberg AE, Eaton AD. Standard Methods for the Examination of Water and Wastewater. USA: American Public Health Association; 1998.

17. Li Z, Yu JW, Neretneiks I. Removal of Pb(II), Cd(II) and $\mathrm{Cr}$ (III) from sand by Electromigration. Journal of Hazardous Materials. 1997;55:295-304.

18. Chang YQ, Tan SN, Yong JWH, Ge L. Surfactantassisted pressurized liquid extraction for determination of flavonoids from Costus speciosus by micellar electrokinetic chromatography. J Sep Science. 2011;34(4):462-468. doi:10.1002/jssc.201000766

19. Bongay DJR, Ngo RL. Electroremediation of Cucontaminated soil. International Journal of Chemical and Biological Engineering. 2012;6:96-101.

20. Acar YB, Gale RJ, Hamed J, Putnam GA. Acid/base distribution in electrokinetic soil processing. Transportation Research Record. 1991;1288:23-34.

21. Saleem M, Chakrabarti MH, Irfan MF, et al. Electrokinetic remediation of nickel from low permeability soil. Int J Electrochem Sci. 2011;96:4264-4275. 
22. Cherifi M, Hazourli S, Ziati M. Initial water content and temperature effects on electrokinetic removal of aluminium in drinking water sludge. Physics Procedia. 2009;2(3):1021-1030. doi:10.1016/ j.phpro.2009.11.058

23. US-DOE (United States Department of Energy). Savannah River Site, Interim Action Record of Decision, Remedial Alternative Selection, SAVANNAH RIVER SITE (USDOE), EPA ID: SC1890008989, OU 08. AIKEN, SC; 1995.

24. US-DOE (United States Department of Energy. Announces Decision on Salt Processing. Environmental Bulletin from the Savannah River Site. 2001;12, Number 16.

25. SRS (Savannah River Site). Environmental Bulletin. 1994;5(28).
26. US-EPA (United States Environmental Protection Agency). Superfund Innovative Technology Evaluation Program: Evaluation of Soil Amendment Technologies at the Crooksville/Roseville Pottery Area of Concern, Rocky Mountain Remediation Services Envirobond Process. Office of Research and Development, 16; 2002.

27. Mu'azu ND, Essa MH, Lukman S. Scale-up of hybrid electrokinetic-adsorption technique for removal of heavy metals from contaminated salinesodic clay soil. Journal of King Saud University Engineering Sciences. 2019;31(2):122-130. doi:10.101 6/j.jksues.2016.12.002

28. Benamar A, Ammami MT, Song Y, Portet-Koltalo F. Scale-up of electrokinetic process for dredged sediments remediation. Electrochimica Acta. 2020;352:136488. doi:10.1016/j.electacta.2020.13648 8 